\title{
Sharing Her Passion for Chemistry and Textbooks
}

\author{
Allison Fleshman teaches her chemistry students how to read textbooks \\ and in doing so instills in them a love and understanding of the subject. \\ By Katherine Wright
}

$\Lambda$ Ilison Fleshman is a physicist in chemist's clothing. At least, that was the impression of her students at Lawrence University, a liberal arts college in Wisconsin. They complained that the physicist turned physical chemist used too much mathematics in her chemistry lessons. But she was able to change their minds with a simple strategy: get them to read their textbook.

Fleshman realized that by focusing on the textbook-in this case, Physical Chemistry by Peter Atkins-she could get more math buy-in from students. So, she decided to switch up her classes and teach students how to read the textbook. The students then taught each other about what they had learned.

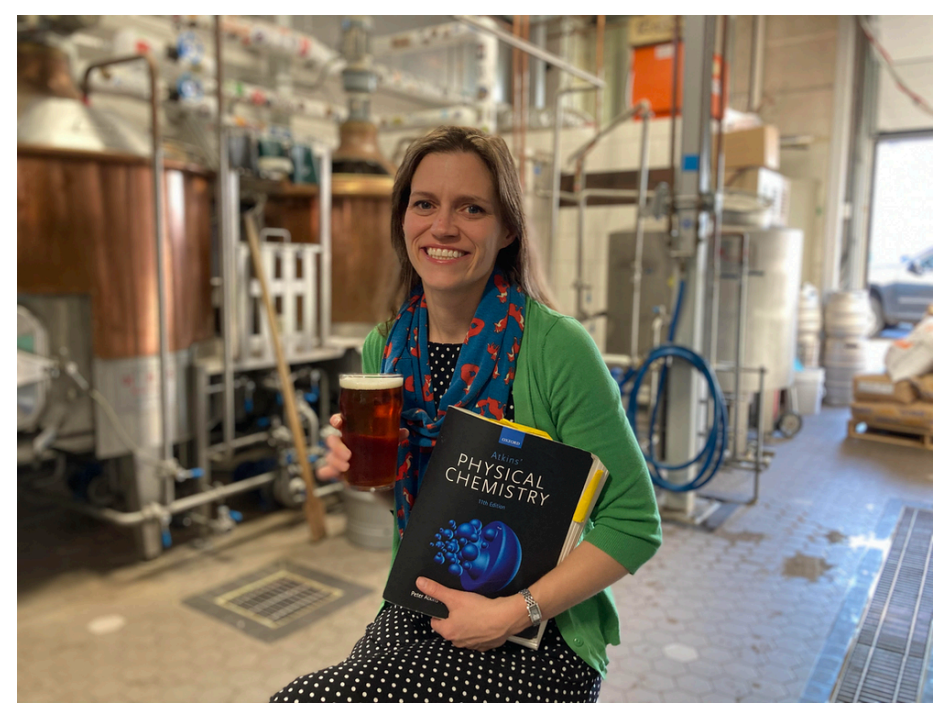

Credit: A. Fleshman
By using this method, known as active reading, Fleshman says that the students became more engaged with the subject, improved their understanding of the material, and developed such a love of the book itself that some of them asked the author to sign their copies. Physics spoke with Fleshman about her passion for textbooks, how she uses them in her classes, and what it's like to be a researcher at a liberal arts college.

All interviews are edited for brevity and clarity.

\section{What is it about textbooks that you love?}

They are comforting. I have a big collection of textbooks in my office, with a few special ones that I keep on my desk. These special books were the ones I delved into when I was struggling to understand some concept. When I saw that there was a textbook gap in the student learning experience, I jumped at the opportunity to fill it.

Tell me about how you use textbooks in the classroom and how it differs from how others might use them. In a traditional class, the lecturer translates the textbook into a set of notes that they give to students. In my physical chemistry class, the students use the textbook to create their own lecture notes.

\section{How does that process work?}

The students work together in groups of three to create a complete set of notes. Each student in the group has a different role, which dictates how they engage with the textbook and what their portion of the notes looks like. They then share those notes with each other and discuss the content. 


\section{What are those roles?}

The highlighter focuses on equations and vocabulary, the visualizer on figures, and the connector on links with previous lessons.

When a student is forced to look at just one element of a textbook's content, I find that they take better notice of that element. Having one thing to concentrate on also helps in guiding the notes they make and the discussion that students have about them in class. For example, the visualizer might talk about how well the figures of a chapter addressed the concepts being discussed, and the connector might go over synergies between equations from different chapters.

\section{What benefits have you seen in teaching this way?}

The "active reading" students are better at interpreting figures and equations. They are also better at making connections between topics and at working out how to solve tricky problems, and they come to class with a higher quality of questions. For example, in an active reading class, I won't have any students asking me which equation they need to use to solve a problem. Rather, they will come asking me to fill in some missing piece of information from their reading.

I have also noticed that students in my active reading class ask more "curiosity" questions. In traditional lectures, there is often little time for curiosity questions because you have a certain amount of content you have to get through. But when the students are organizing the discussions, there is more opportunity to voice those questions. It's remarkable to witness the students flexing that questioning muscle.

\section{And do the students end up loving their textbook as much as you love yours?}

Some of them do. I had three students who went to the American Chemical Society meeting in 2019 and got wind that Peter Atkins was going to be there to publicize the new edition of his textbook. They waited for two hours to meet him so that he could sign their copies. The publisher thought it was hysterical.

\section{On a different note, much of your focus is clearly on teaching. How much time do you get for research?}

Liberal arts colleges are teaching intensive; I spend only about $20 \%$ of my time on research and the rest is devoted to teaching. I like to think that rather than doing science, my job is really to make scientists. Many of my students go on to graduate school or to jobs in industry. So I think I have great success in that.

\section{Is teaching and making scientists what drew you to Lawrence?}

Definitely. That and beer making-my husband and I own a brewery a few blocks from the college. My research program would flourish if I had graduate students, but it's hard to balance all their needs with grant writing and teaching. I also don't think I would be as happy in a more research-oriented institution, because I wouldn't be able to dedicate as much time as I do to being in the classroom, a place I love.

Katherine Wright is the Deputy Editor of Physics. 